\author{
Rocío García Valgañón \\ (Madryt)
}

\title{
LAS ANCIANAS MAYAS PREHISPÁNICAS EN LA ICONOGRAFÍA Y LAS FUENTES COLONIALES
}

\begin{abstract}
The paper offers a revision of the current knowledge concerning elderly Maya women, based on Maya and Spanish colonial sources, as well as iconographic artefacts such as vessels, figurines and mural painting. The main objective is to determine whether information derived from the above sources is congruent and whether it coincides with the current notions about these women. Moreover, special attention is paid to certain roles played by the elderly Maya women, which distinguish them from other female members of the community and, at the same time, bring them almost on a par with men.
\end{abstract}

\section{Key words}

elderly, Maya women, iconography, gender roles, codex, chronicle 
En la Iconografía maya, las representaciones femeninas son mucho menos numerosas que las masculinas, como es habitual entre grupos patriarcales. Si a esto se le añade un sesgo de edad, las imágenes de ancianas son aún más infrecuentes, como corresponde a una sociedad preantibiótica cuyos adultos morían, de media, entre los 25 y los 35 años. Sin embargo, no siempre es claro el sexo o la edad de los personajes; por ejemplo, cuando su imagen está incompleta o dañada. Es el caso de las esculturas prehispánicas yucatecas conocidas como „abuelas”, Ix Nuc ${ }^{1}$ o Xnuk (figs. 1 y 2), posiblemente por influencia del relato del enano y el gobernante de Uxmal recogido por Stephens ${ }^{2}$.

Lo primero será definir qué es lo que se entiende aquí por anciano en el caso de los mayas de Tierras Bajas. Si bien según la Antropología Física podría considerarse como tales a los individuos de 40 ó más años, fuentes coloniales mayas ${ }^{3}$ y españolas ${ }^{4}$ suben esta edad hasta los 50 en adelante; por lo que será esta última - la edad cultural - la que se tenga en cuenta.

A fin de conocer la proporción tanto de mujeres y varones como de ancianos en la iconografía maya prehispánica, se ha analizado la colección de recipientes de Justin $\mathrm{Kerr}^{5}$ en la página Web de $\mathrm{FAMSI}^{6}$, por ser la más completa. De esta muestra se han descartado los considerados no mayas, los procedentes de Honduras y las posibles falsificaciones. Se han seleccionado únicamente los recipientes figurativos con individuos antropomorfos, o bien con animales con rasgos antropomorfos, tales como caminar bípedamente o vestir prendas de ropa. De este modo, la muestra se reduce a dos terceras partes de la original. En estos recipientes se ha identificado a los ancianos, cada uno de los cuales constituye un registro, pudiendo localizarse varios registros en un mismo soporte.

Los ancianos están presentes en el $12 \%$ de la muestra definitiva; un porcentaje similar al de mujeres de todas las edades (11\%), mientras que

\footnotetext{
${ }^{1}$ Ix nuc significa „vieja mujer”, como se recoge en las siguientes obras: A. Barrera Vásquez (dir.), Diccionario Maya Cordemex, México 1980, p. 275; R. Acuña (dir.), Bocabulario de Maya Than, México 1993, p. 634; A. de Ciudad Real, Calepino Maya de Motul, México 1995, p. 394.

${ }^{2}$ J.L. Stephens, Incidents of Travel in Central America, Chiapas and Yucatan, New York 1971.

${ }^{3}$ R. Acuña (dir.), Bocabulario de Maya Than.

${ }^{4}$ A. Ciudad Real, Calepino de Motul, México 1995.

${ }^{5}$ Dado que constantemente se añaden y eliminan registros de esta base de datos, se ha partido de la compilación efectuada por Harri Kettunen (Julio 2015). A esta compilación se han añadido los recipientes clasificados por Kerr como K3120, K6004 y K8587 [online]. Maya Vase Data Base [acceso: 2017-03-20]. Disponible en: <research.mayavase.com/kerrmaya.html>.

${ }^{6}$ The Kerr Collections [online]. FAMSI [acceso: 2017-03-20]. Disponible en: <http://www.famsi. $\mathrm{org} /$ research/kerr>.
} 
los varones están en la práctica totalidad de la muestra. Si introducimos la variable de la edad, encontramos que las ancianas suponen únicamente el 2,7\% del total de mujeres y el 2,5\% del de los ancianos; así mismo, están presentes tan sólo en el $0,24 \%$ de la muestra de recipientes figurativos. Sin embargo, este soporte no es el que tiene menor número de ancianas, pues aún son más escasas en la pintura mural y la escultura monumental. En el extremo opuesto, con el mayor número de ancianas, se encuentran la pequeña escultura y los códices. Puesto que los códices son una fuente iconográfica más acotada que la pequeña escultura, se ha analizado el porcentaje de ancianos de ambos sexos en este soporte. Dicho análisis se ha centrado en los manuscritos de Madrid y Dresde, puesto que no se conocen representaciones de ancianas seguras en el Códice de Paris y durante la realización de esta investigación se consideró que el de Grolier era una falsificacion ${ }^{7}$.

Para averiguar la distribución de los personajes en los códices, se ha partido de los almanaques propuestos por Gabrielle $\mathrm{Vail}^{8}$, con ligeras modificaciones 9 . Los ancianos están presentes en el $45 \%$ de almanaques del Códice Dresde y en el $40 \%$ de los del Madrid, lo que supone una gran presencia de los mayores en este soporte. Sin embargo, teniendo en cuenta que las mujeres de todas las edades suponen únicamente el $5 \%$ de las figuras antropomorfas del manuscrito de Madrid - según Vail y Stone ${ }^{10}$ - no es de esperar una gran presencia de ancianas. Estas últimas son 12, repartidas por 10 almanaques, mientras que las ancianas del Dresde son 8 y están en 7 almanaques, lo que equivale a menos del $5 \%$ y del $8 \%$ del total, respectivamente. Pese a que su porcentaje es muy inferior al de ancianos varones, la diferencia con estos es menor a la existente entre mujeres y varones jóvenes. Así pues, se trata de 20 ancianas de un total de 120 mujeres contabilizadas por Vail y Stone ${ }^{11}$ en estos códices, lo que supone un $16,6 \%$ frente al 2,7\% en los recipientes. Esta diferencia podría deberse al hecho de que en los manuscritos se plasma a deidades, mientras que en los recipientes son más frecuentes las mujeres de carne y hueso.

\footnotetext{
${ }^{7}$ C.F. Baudez, Venus y el Códice Grolier, Arqueología mexicana 10, 55, 2002, pp. 70-79.

${ }^{8}$ G. Vail, The Maya Hieroglyphic Codices [online]. Maya Codices [acceso: 2002-07-13]. Disponible en: $<$ http://mayacodices.org $>$.

${ }^{9}$ Vail (ibidem) identifica 98 almanaques en el Códice de Dresde y 255 en el de Madrid; sin embargo, varios almanaques están repetidos y no presentan diferencias, por lo que cada almanaque y su repetición han sido contabilizados como uno solo, dando como resultado 91 en el primer manuscrito y 245 en el segundo.

${ }^{10}$ A. Stone, G. Vail, Representations of Women in Postclassic and Colonial Maya Literature and Art, [en:] T. Ardren (dir.), Ancient Maya Women, Walnut Creek 2002, p. 208.

${ }^{11}$ Ibidem, p. 217.
} 
Según Tiesler ${ }^{12}$, los mayores de 55 años rondaban entre el 5\% y el 9\% de la población maya prehispánica; un porcentaje inferior a lo observado en códices y recipientes. En cuanto a las ancianas, su presencia en los manuscritos es superior a lo que cabría esperar, mientras que en los recipientes está por debajo de la media. Esta sub-representación es común también a los infantes pues, a pesar de que los menores de 10 años conformaban uno de los sectores más amplios de la población, están poco presentes en las escenas, en especial las niñas.

\section{PRESENCIA DE LAS ANCIANAS MAYAS \\ EN LOS DOCUMENTOS COLONIALES}

Junto con la Iconografía, otra fuente habitual para extraer información sobre las ancianas son los documentos coloniales. De entre estas fuentes destaca la crónica de Diego de Landa ${ }^{13}$, por todos los datos que aporta sobre mujeres mayas. Describe cómo, para ayudar en el embarazo, se acudía a las parteras. No dice que fuesen ancianas, pero las menciona seguidamente de unas mujeres que sí lo eran ${ }^{14}$; lo que pudo llevar a investigadores posteriores a establecer dicha conexión. Curiosamente, son mujeres de edad dudosa los dos personajes que parecen desempeñar este rol en la Iconografía. Se trata de dos recipientes; en el primero (K0559), una mujer sostiene un conejo, aparentemente recién nacido de la Diosa $\operatorname{Lunar}^{15}$ (fig. 3), mientras que la segunda permanece oculta tras la parturienta, sólo mostrando su tocado y garras de jaguar (fig. 4). Sin embargo, otras mujeres en el mismo recipiente-conocido como Vaso del Nacimiento- comparten idéntico tipo de tocado y son ancianas; incluso, una de ellas, también con garras de jaguar, parece participar en otra escena de nacimiento (fig. 5) y, aunque su rostro no es claramente el de una anciana, el pecho si lo es. En cualquier caso, la edad y otras características de las parteras pudieron cambiar con el tiempo y de un grupo a otro, como ocurre en la actualidad. Así, en unas comunidades ejercen como tales las que han alcanzado una edad avanzada y/o ya no tienen

\footnotetext{
${ }^{12}$ V. Tiesler, Rasgos bioculturales entre los antiguos mayas. Aspectos arqueológicos y sociales, Tesis doctoral, México 1999, p. 140.

${ }^{13}$ D. de Landa, Relación de las cosas de Yucatán, México 1973.

14 “(...) en ciertas fiestas a las que admitían a ciertas viejas para la celebración. Para sus partos acudían a las hechiceras", ibidem, p. 58.

${ }^{15}$ S. Martin, M. Miller, Courtly Art of the Ancient Maya, New York 2004, p. 96.
} 
a nadie a su cargo, mientras que en otros grupos, son las que han nacido con un don, lo han heredado, aprendido de sus antecesoras o adquirido después de una enfermedad o evento similar.

Landa tampoco dice que fuesen ancianas - sino las madres - quienes allanaban la cabeza de las criaturas recién nacidas ${ }^{16}$. De hecho, en la Iconografía tan sólo en una figurilla (fig. 6) - o quizá dos (fig. 7) - es una anciana la que sostiene a un niño en una cuna deformadora. En el resto de los casos suele tratarse de mujeres jóvenes, por lo que no hay evidencias iconográficas incontestables de que fuesen únicamente las ancianas las responsables de llevar a cabo tal modificación. Esto es así al menos en Tierras Bajas, pues en Tierras Altas y la Costa Pacífica es más común encontrar a ancianas en este tipo de figurillas.

Lo que si dice Landa es que son las mayores las encargadas de limar los dientes para darles determinadas formas ${ }^{17}$. No obstante, puesto que esta técnica se efectuaba sobre la dentición definitiva - a partir de los 12 años y que los niños que acompañan a las ancianas en las figurillas son menores de esa edad, no parece reflejarse dicha actividad en Iconografía. Tampoco las ancianas cargan a niños sobre las caderas o a hetzmek a pesar de que, en el ritual homónimo ${ }^{18}$, las madrinas ancianas llevan a las criaturas de esta manera. Por otra parte, este ritual no es mencionado por los cronistas, por lo que es probable que no sea de origen prehispánico, sino posterior ${ }^{19}$. En cualquier caso, las ancianas suelen mostrarse con niños de diversas edades; si no como parteras, al menos sí como abuelas, cuidadoras o encargadas de rituales relativos a la infancia ${ }^{20}$.

\footnotetext{
${ }^{16}$ „Y que tenían las cabezas y frentes llanas, hecho también por sus madres”, D. de Landa, Relación, p. 35.

17 „Tenían por costumbre aserrarse los dientes dejándolos como dientes de sierra y esto tenían por galantería y hacían este oficio unas viejas limándolos con ciertas piedras y agua”, ibidem, p. 55.

${ }^{18}$ Este ritual se lleva a cabo cuando las niñas tienen tres y los niños cuatro meses de vida, y tiene por finalidad asignarles sus respectivos roles de género. Generalmente las niñas participan en los rituales a una edad más temprana que los varones; bien porque a las niñas se las vincula simbólicamente con el número 3 y a los niños con el $4 \mathrm{o}$, bien, porque se considere más maduras a las primeras.

${ }^{19}$ V.N. Prieto, N.B. Villanueva, Rituales de hetzmek en Yucatán, Estudios de Cultura Maya 33, 2009, pp. 73-103.

${ }^{20}$ En la festividad de Quecholli, las mujeres con niños les llevaban ante las ancianas que servían en el templo de Mixcoatl y se los entregaban para que éstas los cargasen y acunasen en sus brazos y, posteriormente, éstas se los devolvían a sus madres, B. de Sahagún, Florentine Codex: Book, The Ceremonies 2, III, Santa Fe 1951, p. 126.
} 
Otro rol comúnmente atribuido a las mayores es el de casamenteras. No obstante, para Tierras Bajas, Landa ${ }^{21}$ sólo dice que la ceremonia era oficiada por un sacerdote y que se requería de la participación de casamenteros. $\mathrm{Y}$, a diferencia de lo que sí ocurría en la Provincia del Golfo de Honduras ${ }^{22}$ y en Verapaz ${ }^{23}$, Guatemala, no indica que estos casamenteros fuesen mujeres ni de edad avanzada. En otras ceremonias - referidas al menos desde la Colonia - las ancianas ejercían como madrinas de niñas en rituales de paso. El primero de estos rituales es el Caputzihil o Emku, „Bajada de Dios”, que licenciaba a los jóvenes para contraer matrimonio; mientras que en el segundo, el Olob-Zab-Kamyax, se les inculcaba el oficio de sus padres y madres ${ }^{24}$. En este ritual una anciana llamada Ixmol, „la allegadera”, vestía un hábito de plumas. Al respecto de este atuendo, y no falto de sorna, $\mathrm{Landa}^{25}$ cree que, al final de la fiesta, „aquella devota vieja llevaría con qué emborracharse en casa para no perder las plumas del oficio por el camino". No obstante, si bien los ancianos tenían mayor libertad a la hora de consumir bebidas embriagantes que el resto de la población y es frecuente encontrarles en Iconografía sosteniendo recipientes, la falta de contexto o información sobre su contenido, no permite asegurar que éste fuese alcohólico.

Los ancianos, además de actuar como padrinos de los niños, eran comparados con éstos por cronistas como De Mendieta ${ }^{26}$ y Torquemada ${ }^{27}$, quienes afirmaban que volvían al estado de sencillez y pureza de aquellos; pero también, a un estado de salvajismo. Quizá sea por este motivo que se les representa con rasgos animales y puede resultar complicado saber si se trata de un niño o de un anciano (ver fig. 5). Por otra parte, los cronistas se sorprendían de la seriedad y buen juicio de los infantes pues, según De

\footnotetext{
${ }^{21}$ D. de Landa, Relación, p. 43.

${ }^{22}$ Los señores de la Provincia del Golfo de Honduras, „quando querían casar algún Hijo, embiaban, con Presentes, vn Anciano, á pedir la Hija del otro: éste hacía una larga Relación, de los Hechos de los Pasados del esposo", pero que ésto sólo ocurría con la esposa principal de los señores, mientras que la gente común enviaba a una anciana a por la desposada", A. de Herrera y Tordesillas, Historia general de los hechos de los castellanos en las islas i tierra firme del mar oceano IV, VIII, Madrid 1726-1730, p. 158.

${ }^{23}$ „Enviaba, pues, el señor que la pedía para su hijo, solemnes nuncios y mujeres ancianas y honradas que viniesen con la doncella, la cual traían en los hombros ciertos hombres de bien que habían ido también para ello", B. de las Casas, Apologética historia sumaria 2, México 1967, p. 516. „A la noche los encerraban dos mujeres ancianas y de autoridad, instruyéndolos en cómo ambos se habían de haber", ibidem, p. 517.

${ }^{24}$ D. de Landa, Relación, pp. 99-100.

${ }^{25}$ Ibidem.

${ }^{26}$ G. De Mendieta, Historia eclesiástica indiana, México 1870.

${ }^{27}$ J. de Torquemada, Monarquía indiana, México 1975-83.
} 
Mendieta $^{28}$, obraban y razonaban „como si fueran viejos de cincuenta”. De los ancianos mayas se esperaba que fuesen serios y diesen ejemplo ${ }^{29} \mathrm{y}$, en el contexto mesoamericano ${ }^{30}$, se les encomendaba la salvaguarda de las tradiciones. Eran capaces de relatar lo que había acontecido mucho tiempo atrás mediante la transmisión oral ${ }^{31}$ y la Rueda de Katunes ${ }^{32}$, por lo que se encargaban de educar a los jóvenes. En los „Libros de Chilám Balam” se hace referencia a las ixtitibe o maestras, cuya desgracia ${ }^{33}$ y la de sus sucesores era considerada un mal presagio ${ }^{34}$. Barrera Vázquez identificó como maestra a la anciana del „Cantar 7 de Dzitbalché” que guiaba a las jóvenes en un ritual nocturno de magia amorosa. En este relato su avanzada edad contrasta con la enumeración de cosas nuevas que se estrenaban en el ritual ${ }^{35}$. La tarea de maestra tan sólo se intuye en algunas figurillas de ancianas con niños de pocos años (fig. 8). En cualquier caso, el conocimiento y la experiencia conferían prestigio a los mayores, por lo que la edad avanzada se indicaba tanto en época prehispánica - mediante los títulos Winikhaab ${ }^{36}$ - como colonial ${ }^{37}$.

${ }^{28}$ G. De Mendieta, Historia, p. 503-504.

${ }^{29}$ En El Libro de los libros del Chilam Balam, México 2002, p. 53, se expone la suerte correspondiente a un Katún 5 Ahau, según la cual: „(...) este katún no tendrá sustancia sino destinos de lascivia en las palabras que relajarán la gravedad de los viejos, que relajarán la gravedad de las viejas del 5 Ahau".

${ }^{30}$ Para sus vecinos mexicas, la buena anciana es aquella que „amonesta a la gente/le da voces”, Códice Matritense de la Real Academia, f. 95v, en: M. León Portilla, Cihuayotl iixco ca: la femineidad luce en su rostro, Arqueología Mexicana V, 29, 1998, p. 19.

${ }^{31}$ Uch ben tahn [.1.] can, se traduce como „vejeces o bejedades, cuentos antiguos”, R. Acuña (dir.), Bocabulario de Maya Than, México 1993, p. 632. Por otra parte, chich es tanto "abuela de parte de madre”, A. Barrera Vásquez (dir.), Diccionario Maya Cordemex, México 1980, p. 93, como „palabra o razón”; de donde chich; ah chiich; ah chiich kan significa „diestro en contar cuentos, o notables hechos", ibidem.

${ }^{32},(\ldots)$ con ellos tenía, a maravilla, cuenta de sus edades, y le fue así fácil al viejo (...), había trescientos años después, acordarse de ellos”, D. de Landa, Relación, p. 104.

${ }^{33}$ „No tomarán ya su limosna las Ix Titibe, Maestras. Entonces será el tiempo de la muerte súbita, la que pega y derriba, la que derriba y golpea sacando vómitos de sangre", El Libro de los libros de Chilam Balam, México 2002, p. 115.

34 „Perdidos serán los hijos de las Ixtitibe, Maestras. Entonces vendrá el tributar y el Señor de las dos cabezas vendrá a burlarse de los gobernantes de los pueblos enceguecidos con las difíciles señales del katún", ibidem, p. 81. En cada párrafo se escribe su nombre de manera diferente (Ix Titibe e Ixtitibe).

35 „Nuevo calzado, todo nuevo, inclusive las bandas que atan nuestras cabelleras para tocarnos con el nenúfar”, A. Barrera Vásquez (dir.), Diccionario, p. 369.

${ }^{36}$ Estos títulos indicaban el periodo de 20 años en el que se encontraba su poseedor, siendo que de 0 a 19 años estaba en el $1^{\circ}$ Winikhaab', de 20 a 39 en el $2^{\circ}$, y así sucesivamente. El número más elevado hallado en un título es de 6 Winikhaab' y corresponde a la Señora Pakal, madre de Itzamnaaj Bahlam III de Yaxchilán, Chiapas. Se la menciona en monumentos de este sitio, así como de Dos Caobas (Estela 1); sin embargo, no se conservan retratos suyos para poder conocer su aspecto. 
Posiblemente debido a este prestigio, diversos ancianos - entre los que se cuentan unas pocas mujeres - fueron representados en una posición destacada sobre bancas o tronos (fig. 9).

El de la curación era uno de los conocimientos atribuidos a los mayores ${ }^{38}$. Según Landa, Izamná e Ixchel ${ }^{39}$ eran los dioses de la medicina, pero no hace referencia a la edad de éstos. Si dice ${ }^{40}$, sin embargo, que en el mes de Mac los ancianos rendían culto al primero, y en el mes de Zip eran los médicos y hechiceros los que festejaban a la segunda. Por otra parte, los ensalmos para la curación en el "Ritual de los Bacabes” suelen aludir a las abuelas ${ }^{41}$; aunque, en muchos casos no queda claro si se refieren a mujeres, a plantas curativas o a enfermedades.

Houston, Stuart y Taube ${ }^{42}$ interpretan que la escena del vaso K6020 está relacionada con la curación. Se muestra a una anciana sentada en el suelo y sosteniendo en la mano una vasija (fig. 10) ${ }^{43}$, donde recoge el vómito de otro individuo sentado en una banca. Bajo dicha banca hay otro recipiente que pudiera contener tinta o tizne ${ }^{44}$ (carbón molido con agua); un elemento que, aun hoy día en Yucatán, se emplea para inducir el vómito. La anciana viste un atuendo con motivo de huesos cruzados, al igual que las diosas Tzitzimime del centro de México, a quienes se representaba frecuentemente como ancianas y se las vinculaba tanto con los embarazos y los partos como con la curación ${ }^{45}$. Nuevamente Houston,

\footnotetext{
${ }^{37}$ „Esto es lo que explico, nuestro relato, dentro de la plática, nosotros, Alonso Canché y Pablo Cauich, nunkinienses, hombres ancianos", A. Recinos, Códice de Calkiní, [en:] M. de la Garza (dir.), Literatura maya, Caracas 1980, p. 434.

${ }^{38}$ En el Popol Vuh, México 2000, pp. 36-37, Zaqui-Nim-Ac y Zaqui-Nima-Tziis se presentan ante Vucub Caquix como dos ancianos que viven de la limosna por sacar el gusano de las muelas.

${ }^{39}$ D. de Landa, Relación, p. 93.

${ }^{40}$ Ibidem, p. 78.

${ }^{41}$ En el texto XXXV para la picadura del alacrán, R. Arzápalo Martín, El Ritual de los Bacabes, México 1987, p. 385, se dice: „La sagrada aguja de tu abuela fue la que cogiste y se te introdujo en el miembro, y fue el fuego sagrado de tu abuela”.

${ }^{42}$ S.D. Houston, D. Stuart, K.A. Taube, The Memory of Bones: Body, Being, and Experience among the Classic Maya, Austin 2006, p. 117.

${ }^{43}$ En la esquina inferior izquierda, semioculta por las columnas de glifos, hay una segunda figura anciana de sexo dudoso sosteniendo otra pequeña vasija, por lo que pudo ejercer la misma función.

${ }^{44}$ G. Kantún Rivera, comunicación personal, Mérida, Yucatán 2015.

${ }^{45}$ C. Klein, The Devil and the Skirt: An Iconographic Inquiry into the Pre-Hispanic Nature of the Tzitzimime, Estudios de Cultura Náhuatl 31, 2000, p. 16-74. Otra relación entre las parteras ancianas y la curación se encuentra en la afirmación de R. Redfield y A. Villa Rojas, Chan Kom: A Maya Village, Washington 1964, de que estas quemaban miel bajo la hamaca de las parturientas. Los autores interpretan que la miel pudo ser considerada una panacea tanto para enfermos como para mujeres embarazadas, ibidem, p. 49.
} 
Stuart y Taube ${ }^{46}$ interpretan al personaje que vomita como a un dios escriba con rasgos sobrenaturales; rasgos que también encuentran en la anciana, como los tres puntos en lugar de pupila y las orejas de jaguar. Todo ello les lleva a pensar que la actividad representada no es propia de la vida cotidiana. La anciana tiene una posición muy similar a una de las del vaso K5113 (fig. 11). Se trata del ya mencionado Vaso del Nacimiento, denominado así puesto que Taube ${ }^{47}$ interpreta que se están llevando a cabo rituales relacionados con dicho evento. Pero tampoco en este caso se trata de un parto ordinario, pues la criatura emerge de unas fauces y muestra un aspecto tanto de jaguar como de anciano (ver fig. 5). El hecho de que también la mujer que le recibe muestre rasgos similares, parece indicar que este tipo de rituales pone en contacto la esfera humana con la sobrenatural.

Otra actividad en la que participaban las ancianas era en las celebraciones de Año Nuevo correspondientes a las letras Kan, Ix y Muluc. Ellas eran las únicas mujeres a las que se les permitía el acceso al templo y participaban bailando para aplacar a la deidad ${ }^{48}$. No obstante, se trataba únicamente de ancianas concretas "que para ello tenían elegidas" ${ }^{49}$ y „que tenían por oficio bailar en el templo" ${ }^{50}$. Además, eran las responsables de tejer un paramento para la deidad en las festividades del Año Nuevo de la letra Muluc, por lo que la participación ritual de las mayores - al igual que ocurría en las festividades de Caputzihil y Olob-Zab-Kamyax - parece limitarse a los ritos de paso y a momentos de transición ${ }^{51}$. En cuanto al trabajo textil, hay que diferenciar el destinado al ritual encargado a estas ancianas, del hilado que efectuaban las mujeres que menciona Landa ${ }^{52}$ - sin especificar su edad - y que se ayudaban

\footnotetext{
${ }^{46}$ S.D. Houston, D. Stuart, K.A. Taube, The Memory, p. 117.

${ }^{47}$ K.A. Taube, The Birth Vase: Natal Imagery in Ancient Maya Myth and Ritual, [en:] The Maya Vase Book, New York 1994, pp. 652-685.

${ }^{48}$ Estas mujeres bailaban en tres de las cuatro festividades con motivo del Año Nuevo. En la cuarta, correspondiente a Cauac, los que bailaban eran varones y no necesariamente ancianos. Estas festividades estaban relacionadas con cuatro entidades conocidas como bacabes. quienes podían presentarse como tres ancianos y un joven, C.F. Baudez, B. Riese, Los Bacabs y los monstruos bicéfalos en la arquitectura de Copán, Yaxkin 9, 2, 1986, pp. 77-88. Ésta podría ser la causa de que las ancianas bailasen únicamente en tres de las cuatro festividades.

${ }^{49}$ D. de Landa, Relación, p. 65.

${ }^{50}$ Ibidem, p. 66.

${ }^{51}$ El motivo de huesos cruzados y calaveras de las Tzitzimime del centro de México aparece sobre una plataforma en el Códice Borbónico asociado a los rituales de final del año solar, así como de final del ciclo de 52 años, C. Klein, The Devil and the Skirt, periodo considerado "una vejez" entre los mexicas. Durante estas festividades, las Tzitzimime podían descender con forma monstruosa para devorar a los hombres, B. de Sahagún, Florentine Codex: General History of the Things of New Spain, 7, Santa Fe 1951, p. 27.

${ }^{52}$ D. de Landa, Relación, p. 57.
} 
las unas a las otras para sacar el trabajo adelante. Por otra parte, si bien el tejido parece ser una tarea de las jóvenes en las figurillas, en los códices sólo son ancianas; mientras que el baile parece ser exclusivo de las primeras.

Posiblemente, por el hecho de cumplir funciones específicas de su edad y por el calor acumulado con los años, los ancianos eran considerados cada vez más peligrosos ${ }^{53}$. Por el temor a que se convirtieran en seres fieros, llegó incluso a asesinárseles ${ }^{54}$. Esta era una facultad que compartían con los ancestros, que tenían el poder de convertirse ellos mismos y a otros en animales ${ }^{55}$. Las imágenes de ancianas con rasgos felinos pudieron estar relacionadas con esta capacidad. Entre estas imágenes está la de una figura sedente, comúnmente identificada como Diosa $\mathrm{O}$ o Chak $\mathrm{Chel}^{56}$, y ubicada en la esquina superior derecha del vaso K0501 (fig. 12). Ésta tiene orejas y garras de jaguar y grandes ojos cuadrangulares de deidad, un tipo de frente asociada a este tipo de ojos y marcas de brillo sobre el brazo; rasgos éstos inusuales en representaciones femeninas. Lleva un colgante de concha cortada $\mathrm{u}$ oyouhualli al cuello, relacionado con el Dios $\mathrm{N}$ maya y con los de la danza, la música y las artes del centro de México ${ }^{57}$. Tiene una banda sobre el pecho con una insignia cuadripartita a la espalda, al igual que dos personajes con rasgos felinos y posiblemente masculinos: el vaso K0954 y el portaespejo K1955. La insignia cuadripartita está relacionada tanto con el sacrificio como con el sol, elementos asociados al Dios Jaguar del Inframundo. Lo que parece ser cabello atado sobre la frente de la figura del vaso K0501 es igualmente característico de dicha deidad; sin embargo, en lugar de en un moño, el atado acaba en una cabeza de serpiente, como es habitual en tocados de mujeres vinculadas con la lluvia. La asociación entre el atado de cabello y la cabeza de serpiente no es usual y puede deberse a que el vaso fue restaurado y repintado, por lo que este detalle pudo ser modificado. Sin embargo, en un

\footnotetext{
${ }^{53}$ Los itzaes „tienen la costumbre que en pasando de cincuenta años, degollarlos, porque no aprendan a ser brujos y los maten", A. de Avendaño y Loyola, Relación de las dos entradas que hice a la conversión de los gentiles itzaes y cehaches, México 2004, pp. 50-51.

${ }^{54}$ Entre los mexicas „Podía acontecer que un hombre, después de haber llegado a la ancianidad, viviera todavía otro siglo más y alcanzase a cumplir los 104 años, entonces tenían gran miedo y se apartaban de él, diciendo que ya no era hombre, sino fiera animal", F. Cervantes de Salazar, Crónica de la Nueva España 1, México 1914-36, p. 59.

${ }^{55}$ „Allí fueron transformados en caimanes por su abuelo Ah Yamás, Señor de la orilla del mar”, A. Médiz Bolio, Libro de Chilam Balam de Chumayel, [en:] Mercedes de la Garza, Literatura maya, Caracas 1980, p. 222.

${ }^{56}$ S. Martin, M. Miller, Courtly Art of the Ancient Maya; K.A. Taube, The Birth Vase.

${ }^{57}$ K.A. Taube, Ritual Humor in Classic Maya Religion, [en:] W.F. Hanks, D.S. Rice (dir.), Word and Image in Maya Culture, Salt Lake City 1989, pp. 351-382.
} 
dibujo de un vaso de Tierras Altas se presenta a un varón con tocado de cabeza de serpiente similar (fig. 13), sentado a la derecha de la escena en una posición más elevada que el resto de los personajes y con marcas de brillo sobre el brazo, como en el vaso K0501. Por lo tanto, el personaje en este último vaso podría ser masculino. Sin embargo, la prenda que viste es más larga que la del resto de individuos de ambas escenas, la mayoría masculinos, por lo que podría tratarse de una falda femenina. Además, bajo el brazo asoma lo que pudiera interpretarse como un pecho femenino; aunque no es algo seguro, pues queda semioculto bajo dicha extremidad ${ }^{58}$. Por otra parte, su aspecto es similar al de la diosa Chak Chel en las páginas 67a y 74 del Códice de Dresde, por las garras, el tocado de serpiente, los ojos de deidad y la boca blanca a diferencia del resto del rostro. Así pues, debido a que tiene rasgos tanto de varón como de mujer, no se puede determinar su sexo. No obstante, esta indefinición es un rasgo característico de la vejez pues, en esa edad, las diferencias físicas y de género entre los sexos parecen diluirse. Este hecho pudiera estar relacionado con la percepción de los ancianos como seres completos, como "padres-madres” de la comunidad, aún en la actualidad ${ }^{59}$.

\section{RASGOS BÉLICOS E INFLUENCIAS FORÁNEAS}

En la edad avanzada las mujeres muestran un aspecto bélico inusual entre las jóvenes. Es el caso de la figurilla de una anciana armada con un escudo y un elemento cilíndrico (fig. 14$)^{60}$, que ha sido identificada como Chak Chel por sus rasgos de jaguar y su aspecto fiero ${ }^{61}$. Recuerda a las "parteras y ancianas nahuas" ${ }^{62}$, que se armaban para proteger a las mujeres muertas

\footnotetext{
${ }^{58}$ Este brazo podría estar repintado pues no muestra la muñequera presente en la muñeca opuesta y su grosor es muy inferior.

${ }^{59}$ R. García Valgañón, La representación de las ancianas mayas prehispánicas mayas de Tierras Bajas desde una perspectiva de género, Tesis Doctoral, Madrid 2016, p. 514.

${ }^{60}$ Según M. Miller y S. Martin, Courtly Art of the Ancient Maya, p. 117, este objeto tendría un origen moderno.

${ }^{61}$ C.T. Halperin, Maya Figurines: Intersections between State and Household, Austin 2014, p. 136; L. Schele, Hidden Faces of the Maya, California 1997, p. 164.

${ }^{62}$ La patrona de los partos entre los nahuas era Cihuacóatl, la diosa madre muerta cuando daba a luz e, igualmente, „mujer guerrera”, P. Johansson, Mocihuaquetzqueh ¿mujeres divinas o mujeres siniestras?, Estudios de Cultura Náhuatl 37, 2006, p. 216.
} 
durante el parto de los ataques de guerreros y „brujos” que pretendían hacerse con partes del cuerpo de aquellas ${ }^{63}$.

Otra imagen femenina en un contexto bélico es la del Monumento 148 de Toniná (fig. 15), que sujeta por el cabello a un varón y, con la otra mano, sostiene un cuchillo con el que parece que le va a sacrificar ${ }^{64}$; una escena acorde con el estilo beligerante de Toniná y con la ubicación del monumento en una cancha de juego de pelota. Por otra parte, al ser la escultura monumental un soporte público, el cuerpo de las mujeres suele quedar totalmente oculto; por lo que es excepcional que, en este caso, aparezca con un pecho al descubierto. Y, dado que se halló otra mujer en el mismo tipo de soporte en Chichén Itzá con el pecho descubierto y anciana, es posible que la de Toniná también lo sea. Sin embargo, puesto que su rostro está erosionado, no se puede asegurar. Ayala Falcón la ha identificado como un ancestro del gobernante del sitio, representada como Chak $\mathrm{Chel}^{65}$, por la importancia que tuvieron las diosas en los levantamientos mayas durante la Conquista. Relaciona esta imagen con la ofrecida por Díaz del Castillo del combate de los españoles contra los chiapanecas, quienes llevaban entre sus filas a una anciana a la que consideraban diosa y que se autosacrificó en la batalla ${ }^{66}$. Frecuentemente también se ha identificado a las mujeres en los cuatro lados de la columna interior norte del Templo Inferior del Jaguar de Chichén Itzá67 (fig. 16) con

${ }^{63}$ El cuerpo de la parturienta muerta era transportado y protegido por su esposo y por „todas las parteras y viejas” en comitiva: „Iban todos con rodelas y espadas y dando voces, como cuando vocean los soldados al tiempo de acometer a los enemigos, y salíanlas al encuentro los mancebos que se llaman telpopochtin, y peleaban con ellas por tomarles el cuerpo de la mujer, y no peleaban como de burla, o como por vía de juego, sino peleaban de veras”, B. de Sahagún, Historia general de las cosas de Nueva España, México 1829, p. 380.

${ }^{64}$ Curiosamente, y a pesar de ser la mujer la que sostiene a su adversario por el pelo mientras que en la otra agarra un arma, S.D. Houston, D. Stuart, K.A. Taube, The Memory of Bones, p. 208, han interpretado que se trata de una escena de violación en la que el varón es el agresor. Sin embargo, hacen una interesante observación al apuntar que la mujer muestra glifos sobre el muslo, como suele verse en cautivos, por lo que la interpretación de la escena ha de tomarse con precaución.

${ }^{65}$ M. Ayala Falcón, Lady K'awil, Goddess O, and Maya Warfare, [en:] T. Ardren (dir.), Ancient Maya Woman, pp. 105-113.

${ }^{66}$ Los chiapanecas „entonces traían en medio de sus escuadrones una india algo vieja/y muy gorda, y, según decían, aquella india la tenían por su diosa y adivina, y les había dicho que así como ella llegase donde estábamos peleando, que luego habíamos de ser vencidos, y traía en un brasero unos sahumerios y unos ídolos de piedra, y venía pintada todo el cuerpo y pegado algodón a las pinturas, y sin miedo ninguno se metió entre los indios nuestros amigos, que venían hechos un cuerpo con sus capitanías, y luego fue despedazada la maldita diosa”, B. Díaz del Castillo, Historia verdadera de la conquista de la Nueva España, México 2005, pp. 421-422.

${ }^{67}$ P. Mathews, L. Schele, The Code of Kings: The Language of Seven Sacred Maya Temples and Tombs, New York 1998, p. 216. 
Chak Chel. Por ejemplo, la representada en la p. 74 del Códice de Dresde tiene en común con las mujeres de Chichén Itzá la falda de huesos cruzados y el pecho descubierto; aunque no presenta el rostro esquelético de estas. Sin embargo, este es un rasgo característico de las Tzitzimime del Centro de México; un área con gran influencia en esta urbe maya. Otro rasgo que comparten con las mujeres de Chichén Itzá es su papel como sostenedoras del peso del cielo o la tierra sobre sus cabezas ${ }^{68}$.

Volviendo a la anciana en la escultura monumental de esta misma ciudad (fig. 17), se trata de la única representación femenina de edad avanzada segura en este tipo de soporte. Como las mujeres de rostro descarnado, decora uno de los laterales de un pilar o columna; $y$, al igual que estas, muestra similitudes con la iconografía del centro de México. En una mano sostiene un bastón y en la otra, una vasija por el asa, y acompaña en procesión a sacerdotes y cautivos. Este conjunto recuerda a las comitivas en las festividades de Quecholli y Panquetzaliztli del centro de Méxíco, descritas por Sahagún ${ }^{69}$, en las que participaban las teixamique, "las que lavan la cara a la gente" ${ }^{70}$. En la festividad de Quecholli, estas mujeres alimentaban a los sacrificados con tamales y salsa de sus jícaras ${ }^{71}$, posiblemente similares a la que porta la señora de Chichén Itzá. En la festividad de Quecholli se las identifica como ancianas ${ }^{72}$; sin embargo, en la de Panquetzaliztli sólo se dice que se trataba de una mujer $^{73}$. No obstante, seguidamente se habla de unas ancianas que bebían vino junto con los hombres tras el sacrificio ${ }^{74}$. Por lo tanto, el hecho de presentar a mujeres mayores en escultura monumental con el pecho expuesto pudo deberse a influencias del centro de México.

\footnotetext{
${ }^{68}$ C. Klein, The Devil and the Skirt; E. Seler, Gesammelte Abhandlungen zur Amerikanischen Sprach- und Alterthumskunde, Berlin 1902-1923, pp. 90-91.

${ }^{69}$ E. Mazzetto, comunicación personal, 2014.

${ }^{70}$ P. Máynez, El calepino de Sahagún: un acercamiento, México 2002, p. 234.

${ }^{71}$ „Estaban abajo cerca del lugar donde espetaban cabezas, dos mugeres viejas que llamaban Teixamique: tenían junto á si unas jícaras con tamales, y una salza de molli en una escudilla, y en descendiendo á los que habían muerto, llevábanlos donde estaban aquellas viejas, y ellas metían en la boca á cada uno de los muertos cuatro bocadillos de pan mojados en la salza, y rociabanlos las caras con unas hojas de caña mojadas en agua clara”, B. de Sahagún, Historia General, p. 167.

${ }^{72}$ Este dato aparece en la versión española de Sahagún de la Historia General, pero no en la edición bilingüe nahuatl-inglés, B. de Sahagún, Florentine Codex: Book, The Ceremonies, III.

${ }^{73}$ „(...) the woman who was to bathe [the slaves] bathed herself at the water's edge”, ibidem, II, p. 131.

${ }^{74}$ „And upon the next day, all drank wine; all began the drinking. (...) All the old men, the old women, the warriors of noble lineage, they who had wives, the men of marriageable age, and the nobility, and the leaders of nobility-they drank the wine", ibidem, p. 137.
} 
Llama la atención que las figuras femeninas mencionadas vinculadas con la guerra y el sacrificio se hallen en Toniná y Chichén Itzá, puesto que en ambos sitios el sistema de parentesco fue atípico y las mujeres jugaron un papel destacado en el traspaso del poder. Posiblemente, su representación respondió a un intento por parte de sus sucesores de dotarlas de un carácter sobrenatural que contrarrestara el hecho de no haber heredado el poder por línea paterna, como era la norma.

La relación entre las ancianas, la guerra y el sacrificio es reforzada por la presencia del motivo de huesos cruzados. Además de con la curación, este símbolo se asocia con la muerte y el Inframundo, pero también con la renovación ${ }^{75}$, por lo que adorna el atuendo tanto de los verdugos como de sus víctimas. En el Códice de Dresde se relaciona con el Dios A y con otras deidades de la muerte; así como con un Dios $\mathrm{D}$ con pecho femenino ${ }^{76}$ (fig. 18) y con la diosa Chak Chel de la p. 74 (fig. 19), posiblemente debido al carácter destructor de las aguas que arroja. Se encuentra también en el vaso de Calcehtok, adornando el atuendo de un venado - generalmente identificado con las víctimas de sacrificio (fig. 20) - así como el de una estatua acéfala de Oxkintok (fig. 21), con el pecho triangular y descolgado de las ancianas. Así pues, este motivo se relaciona con los rasgos felinos o monstruosos, y con un carácter liminal y dual, como en el caso de las Tzitzimime. En la mayoría de las ocasiones, éstas eran benefactoras, como patronas de la curación y los embarazos; pero, cada 52 años, había riesgo de que bajaran a la tierra con aspecto monstruoso y devoraran a sus habitantes (Klein 2000).

Una imagen totalmente opuesta es la que presentan dos mujeres mayores en la pintura mural de Calakmul y Chilonché; ambas agachadas frente a otro individuo erguido. La de Calakmul está acuclillada sosteniendo un gran recipiente sobre su cabeza (fig. 22), al igual que una joven en las mismas pinturas; por lo tanto, no se trata de un rol exclusivo de la edad avanzada, sino que era común entre las mujeres. En el caso de la anciana, llama la atención la posición acuclillada que adopta y las dimensiones - y quizá el peso- del recipiente que sostiene, pues parece requerir de la ayuda de un varón. Por su parte, la de Chilonché muestra una pronunciada inclinación del torso frente a una mujer más joven y erguida (fig. 23), como un posible

\footnotetext{
${ }^{75} \mathrm{H}$. Hernández Álvarez, Ideología de género femenino en la época prehispánica: diosas mayas con atuendos de sacrificio y muerte, Temas Antropológicos 28, 1-2, 2006, pp. 155-178.

${ }^{76}$ Éste lleva, además, un cinturón de hueso, como se observa en una mujer del Códice Vaticano e identificada como Cihuateteo y vinculada con las Tzitzimime, C. Klein, The Devil and the Skirt, p. 27.
} 
gesto de sumisión. Sin embargo, junto a ambas ancianas aparecen sendos glifos nominales que las identifican, por lo que debieron ser personajes de cierta importancia, pues la mayoría de las figuras de Chilonché no son identificadas del mismo modo. El nombre de la mujer de estas pinturas es Ix Sutz, "Señora Murciélago"77, mientras que en el caso de la mujer de Calakmul sólo se distingue el glifo ix(ik), que identifica a las mujeres ${ }^{78}$. En cualquier caso $\mathrm{y}$ al margen del importante rol jugado por ancianos ${ }^{79} \mathrm{y}$ mujeres, las tareas que desempeñan en estas imágenes pueden responder a su posición secundaria en la sociedad, especialmente la de aquellas que quedaban viudas ${ }^{80} \mathrm{y}$ sin hijos, lo que suponía una falta de protección y la posibilidad de convertirse en chivos expiatorios $^{81}$.

A lo largo del tiempo y de los diferentes soportes, se van apreciando cambios en la representación de estas mujeres. Las figurillas femeninas del Clásico Tardío y Terminal tienen aspecto humano (con la excepción de la anciana guerrera) y se limitan a sostener niños y animales y a tareas cotidianas similares. El hecho de que estas figurillas se parezcan tanto entre sí pudo deberse a que representasen a personajes teatrales ${ }^{82} \mathrm{o}$ a arquetipos sociales,

${ }_{77}$ A. Lacadena García-Gallo, comunicación personal, 2015.

${ }^{78}$ S. Martin, Hieroglyphs from the Painted Pyramid: The Epigraphy of Chiik Nahb Structure Sub 1-4, Calakmul, México, [en:] C. Golden, S.D. Houston, J. Skidmore (dir.), Maya Archaeology 2, San Francisco 2012, p. 70.

${ }^{79}$ En el Popol Vuh, pp. 36-37, aparecen en un par de ocasiones parejas de ancianos pobres. En primer lugar, la pareja compuesta por Zaquí-Nim-Ac y Zaqui-Nimá-Tziís vive de la limosna por sacar el gusano de las muelas; $y$, en segundo lugar, los héroes gemelos se hacen pasar por „dos pobres, de rostro avejentado y aspecto miserable, vestidos de harapos y cuya apariencia no los recomendaba", ibidem, p. 95.

${ }^{80}$ „Será el flechar entonces a los huérfanos de padre, al miserable, a la viuda, para sustentar su corazón”, El libro de los libros de Chilam Balam, México 2002, p. 91; „(..) fueron matados a flechazos los huérfanos, los desamparados y las viudas, que vivían sin fuerza para vivir", El Libro de Chilam Balam de Chumayel, México 1991, p. 52.

${ }^{81}$ En épocas de crisis, en Guatemala se buscaba a la mujer más anciana, la llevaban fuera del pueblo a un cruce de caminos y allí la rodeaban. Entonces, en voz alta y todos a un tiempo confesaban públicamente sus pecados y, cuando habían terminado, un sacerdote se le acercaba con una gran piedra y la golpeaba en la cabeza hasta matarla. Tras ésto, se acercaban todos los confesantes y la cubrían con piedras, erigiéndole así un gran enterramiento monumental. Cuando acababan, volvían a sus casas convencidos de que el pueblo había sido purificado y todos sus pecados quedaban sobre los hombros de la anciana, para que les representara ante sus dioses y apaciguara la ira de éstos, T. López Medel, Ordenanzas para la provincia de Yucatán (1552-1553), [en:] A. Tozzer, Landa's Relacion de las cosas de Yucatan. A Translation, Cambridge 1941, p. 226.

${ }^{82}$ D. Triadan, Warriors, Nobles, Commoners, and Beasts: Figurines from Elite Buildings at Aguateca, Guatemala, Latin American Antiquity 18, 3, 2007, pp. 269-293; J.P. Laporte, El embrujo del tecolote y otras historietas: Algunas consideraciones sobre los silbatos del Clásico en Tikal, [en:] B. Arroyo, J.P. Laporte, H. Mejía, XXII Simposio de Investigaciones Arqueológicas en Guatemala, 
por lo que mostrarían la idea que estas sociedades tenían de sus ancianas y lo que esperaban de ellas. En la pintura mural de esta época - al menos en Calakmul - también parecen desempeñar tareas cotidianas, como cargar recipientes; mientras que en los vasos pintados, aparentan tomar parte en rituales. Su aspecto es humano aunque, en este último soporte, es más común encontrarlas con rasgos de jaguar, por su carácter liminal o por su identificación con la diosa Chak Chel. Ya en el Clásico Terminal y en el Posclásico, su presencia se limita a una aparición en escultura monumental - con posible influencia foránea - y a una veintena de diosas en los códices quienes, debido a su carácter sobrenatural, muestran un abanico de actividades más amplio. La anciana representada en la pintura mural de Tulum en este periodo es posiblemente también una deidad (fig. 24). Se sienta sobre una superficie elevada del suelo a la derecha de la escena, lo que le confiere mayor importancia que al personaje erguido frente a ella, identificado como deidad de la lluvia ${ }^{83}$. En el profuso tocado de la anciana se distinguen una serpiente anudada y un huso de hilar, como ocurre entre sus homólogas en los códices, por lo que ha sido identificada como Chak Chel o Diosa $\mathrm{O}^{84}$; sin embargo presenta más semejanzas con el estilo Mixteca-Puebla del centro de México que con el maya.

En este mismo periodo, los varones empiezan a apropiarse de aspectos o atuendos femeninos, lo que pudiera indicar una mayor pérdida de poder por parte de las mujeres. Es el caso de los donantes de Chichén Itzá (fig. 25), algunos de ellos ancianos vistiendo falda y cargando recipientes con comida pero sin pechos femeninos ${ }^{85}$. Por otra parte, en esta misma ciudad se encuentra el caso inverso, el de un varón de edad dudosa con falda de serpientes y pecho femenino, al que Linnea Wren ${ }^{86}$ identificó como Cihuacoatl o jefe militar del centro de México (fig. 26). Pese a que Cihuacoatl en nahuatl significa „Mujer Serpiente" ${ }^{77}$, es un cargo desempeñado por un varón, lo que supone una apropiación del nombre ${ }^{88} \mathrm{y}$ de atributos femeninos por parte de los varones ${ }^{89}$.

Guatemala 2009, pp. 1021-1050. Igualmente, muchas de estas figurillas fueron realizadas con los mismos moldes, lo que explica las semejanzas existentes ellas.

${ }^{83}$ D. Finamore, S.D. Houston, Fiery Pool. The Maya and the Mythic Sea, New Haven 2010, p. 215.

${ }^{84}$ K.A. Taube, The Major Gods of Ancient Yucatan, Washington 1992, p. 102.

${ }^{85}$ R.A. Joyce, Gender and Power in Prehispanic Mesoamerica, Austin 2000, p. 109.

${ }^{86}$ Linnea Wren hizo esta identificación en su presentación al XIX Texas Meeting on Maya Hieroglyphic Writing, en 1995, [en:] P. Mathews, L. Schele, The Code of Kings, p. 373, nota 64.

${ }^{87}$ Nótese la falda de serpientes entrelazadas entre si, como la asociada a la diosa Cihuacoatl.

${ }^{88}$ R.A. Joyce, Gender and Power in Prehispanic Mesoamerica.

${ }^{89}$ C. Klein, The Devil and the Skirt. 
Este fenómeno pudo deberse al auge de modelos y valores masculinos y militares en las últimas etapas de la Historia prehispánica.

\section{COMENTARIOS}

A lo largo de estas páginas se ha analizado la imagen de las ancianas mayas prehispánicas de tierras bajas principalmente en los códices y en los documentos coloniales, a fin de comparar la informacion vertida por ambas fuentes.

En las representaciones iconográficas se ha observado que la naturaleza de estas mujeres es más comúnmente humana que en el caso de los varones; se las muestra como arquetipos sociales, especialistas rituales debido a su carácter liminal y como diosas patronas de tareas femeninas. Por lo general, el abanico de roles y escenas asociado a las mujeres es más limitado que el masculino. Por otra parte, no se encuentran correspondencias iconográficas a diversos roles femeninos mencionados en los textos. Así mismo, se ha comprobado que algunas asociaciones que se establecen en la actualidad entre las ancianas y oficios como los de partera y casamentera no tienen una base sólida en las fuentes coloniales, al menos para Tierras Bajas. Tampoco hay evidencias irrefutables de que fuesen mayores las que deformaban el cráneo de los recién nacidos, ni que les cargasen sobre la cadera en el ritual del hetzmek durante la Colonia. No obstante, sí que eran ancianas las que limaban los dientes para embellecerlos y participaban en rituales de paso para que los niños aprendiesen el oficio de sus padres y pudieran casarse. Así mismo, algunas de ellas participaron en rituales que implicaban danza, tejido $\mathrm{y}$, posiblemente, curación y nacimiento.

En definitiva, las tareas que llevaron a cabo las ancianas son menos numerosas que las de los varones mayores; sin embargo, presentan roles diferentes al resto de mujeres, pero que fueron desempeñados igualmente por algunos varones ancianos y personajes de edad y sexo dudosos. Esto se debe al hecho de que, según envejecen, parecen ir asimilando aspectos y roles del sexo opuesto, y convirtiéndose en personas más completas. Esta transformación se manifiesta en la feminización de los varones y, en el caso femenino, en el aumento de su autoridad, de su participación ritual y de la manifestación de rasgos de divinidad; posiblemente debido al hecho de asemejarse cada vez más a los varones en una sociedad patriarcal. 


\section{AGRADECIMIENTOS}

No quisiera terminar sin agradecer antes a D. Kajetan Jagodziński todas las gestiones realizadas, así como su apoyo, y al Dr.Alfonso Lacadena sus invaluables aportes a esta investigación.

\section{Rocío García Valgañón \\ STARSZE KOBIETY W KULTURZE MAJÓW PREKOLUMBIJSKICH W IKONOGRAFII I ŹRÓDŁACH KOLONIALNYCH}

\section{Streszczenie}

Przedstawienia starszych wiekiem kobiet Majów spotyka się znacznie rzadziej niż jest to w przypadku ich męskich odpowiedników. Również role jakie owe kobiety odgrywały są bardziej ograniczone. Niemniej, różnice w tym względzie nie są tak znaczące jak między młodymi kobietami i mężczyznami. Co więcej, starsze wiekiem Majanki uczestniczyły w rytuałach w znacznie większym zakresie niż młode kobiety, a ich prestiż wzrastał. Prawdopodobnie wynikało to $\mathrm{z}$ faktu, że $\mathrm{w}$ patriarchalnym społeczeństwie stawały się coraz bardziej podobne mężczyznom. 


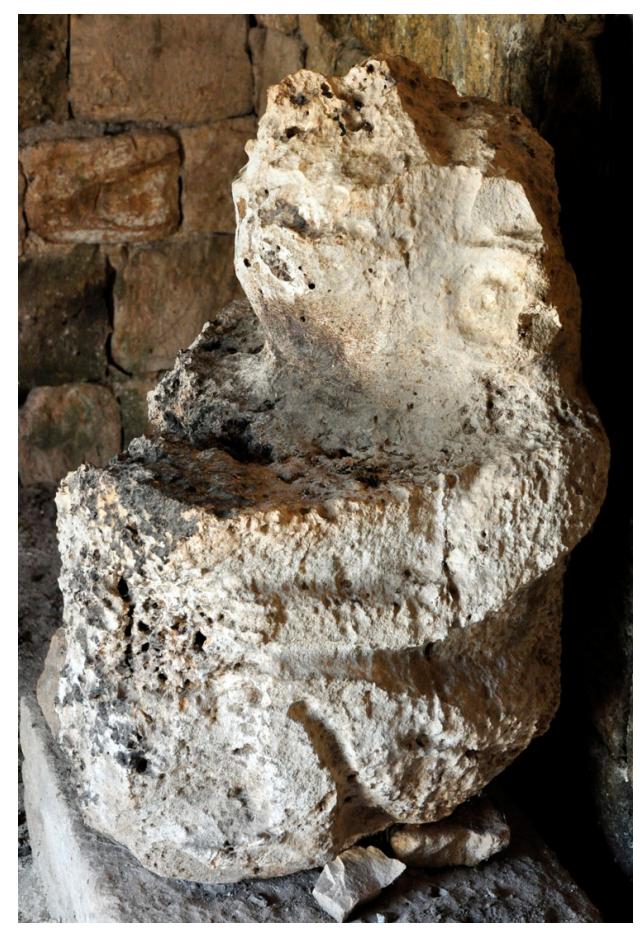

Fig. 1. Escultura de Xcalumkin, fotografía de Ivan Sprajc

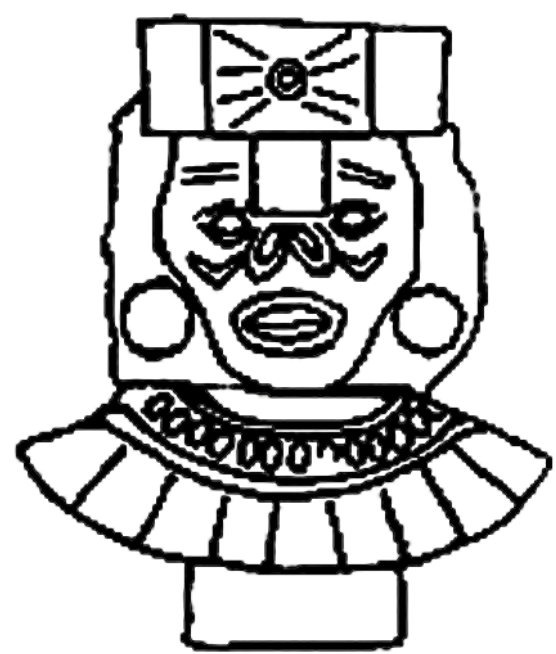

Fig. 2. Escultura de La Vieja o Vírgen de Santa Rita, en S. Patel, Pilgrimage and Caves on Cozumel, p. 106, fig. 5.6 


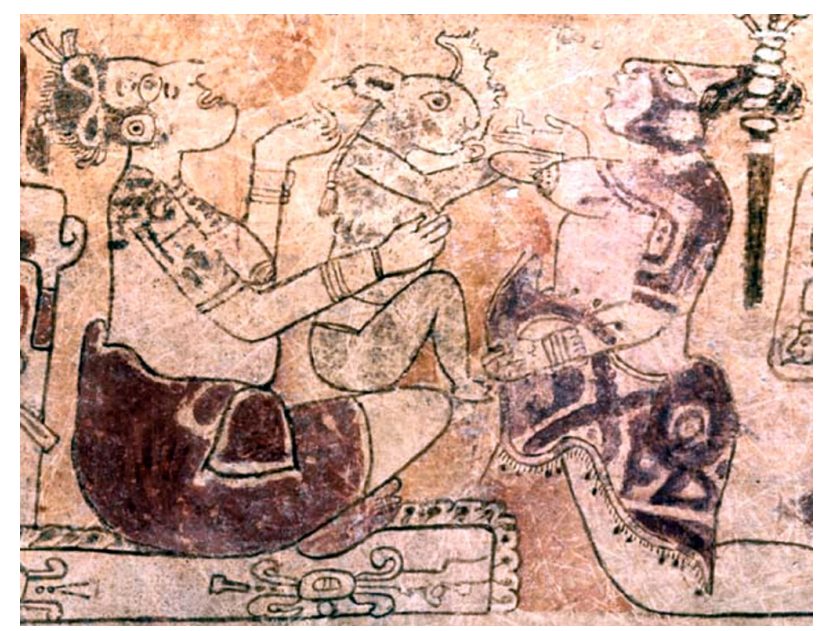

Fig. 3. Vaso K0559 (detalle) [online]. FAMSI [acceso: 2017-06-05]. Disponible en: $<$ http://research.mayavase.com/kerrmaya_list.php?_allSearch=\&hold_search=\&vase_nu mber $=559 \&$ date_added $=\& m s \_$number $=\&$ site $=\& \mathrm{x}=0 \& \mathrm{y}=0>$

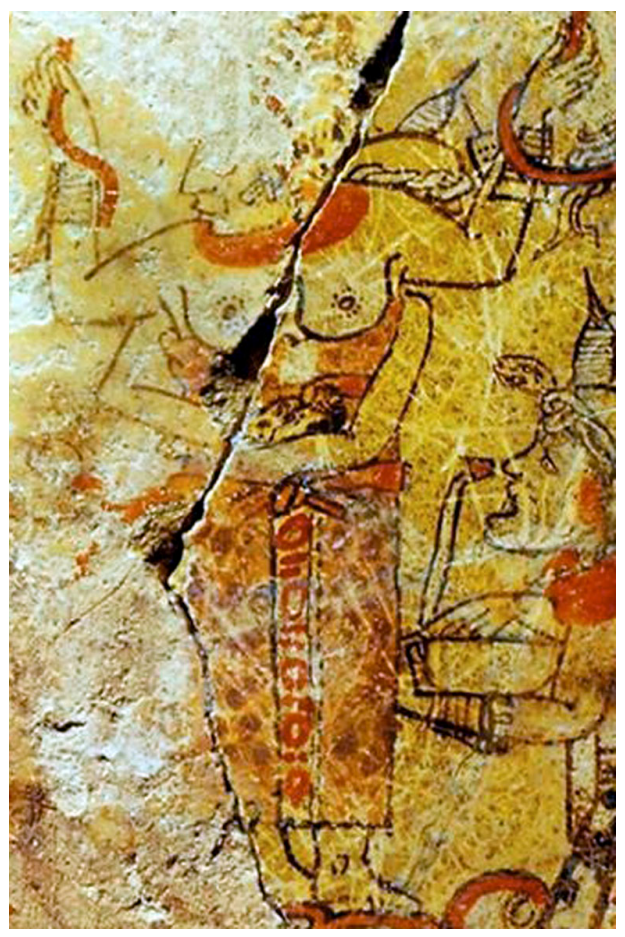

Fig. 4. Vaso del Nacimiento, K5113, lado 1 (detalle) [online]. FAMSI

[acceso: 2017-06-05]. Disponible en: <http://www.mayavase.com/5113/birthvase.html> 


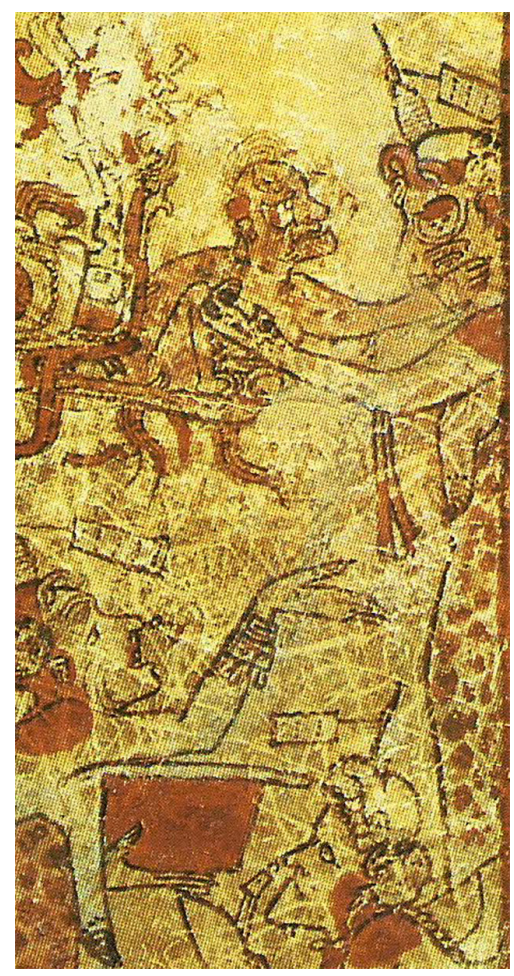

Fig. 5. Vaso del Nacimiento, K5113, lado 2 (detalle) [online]. FAMSI

[acceso: 2017-06-05]. Disponible en: <http://www.mayavase.com/5113/birthvase.html >

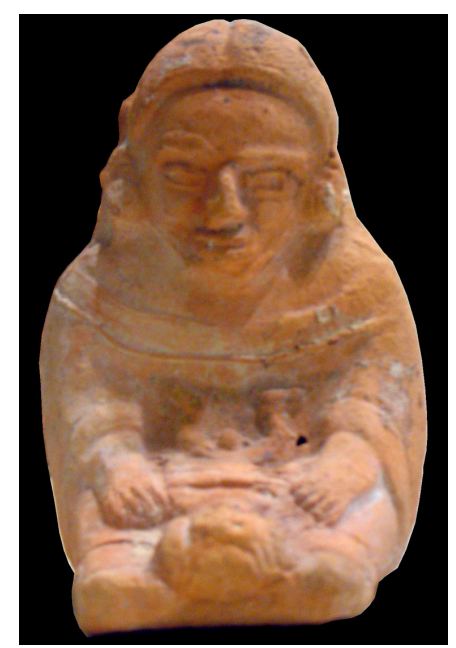

Fig. 6. Figurilla femenina, en P. Moya Honores, La representacion material de los roles femeninos y las relaciones de genero, p. 239 


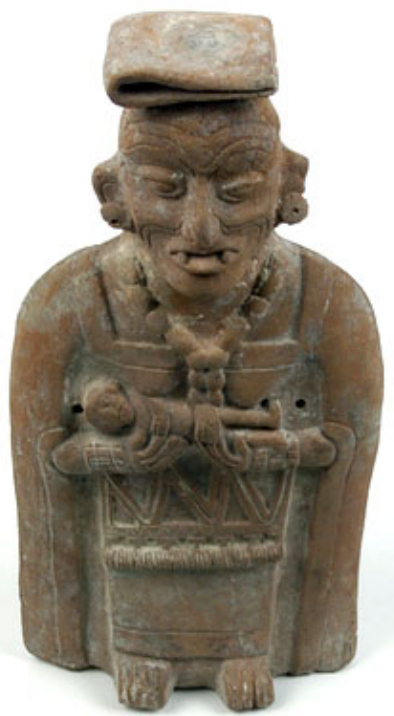

Fig. 7. Figurilla femenina, fotografía del National Museum of the American Indians

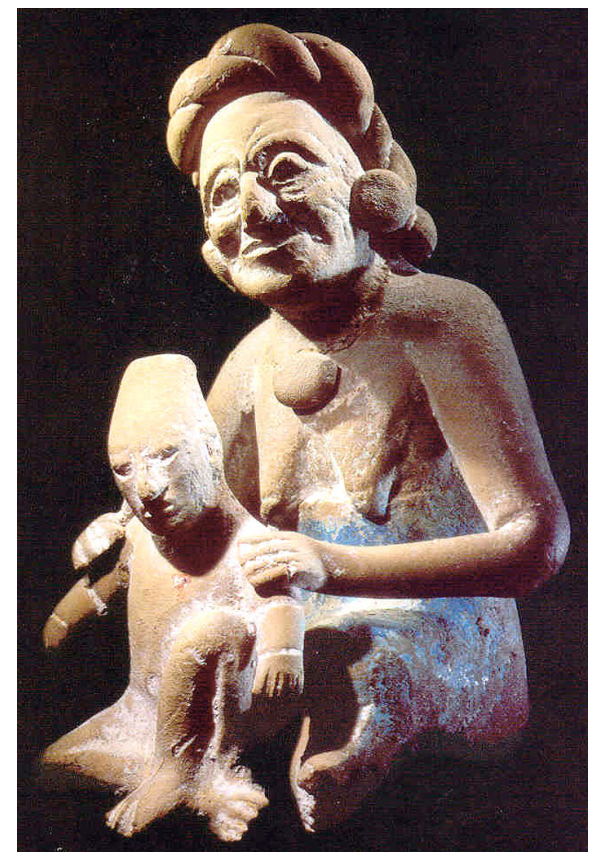

Fig. 8. Figurilla femenina, fotografía de Jorge Pérez de Lara, en L. Schele, Rostros Ocultos pl. 32 


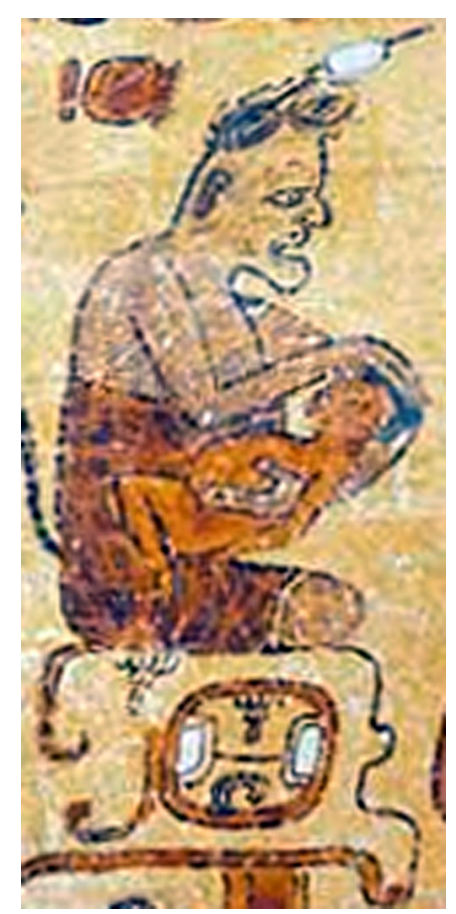

Fig. 9. Vaso K5451 (detalle) [online]. FAMSI [acceso: 2017-06-05]. Disponible en: $<$ http://research.mayavase.com/kerrmaya_list.php?_allSearch=\&hold_search=\&vase_nu mber $=5451 \&$ date_added $=\& m s \_n u m b e r=\& \operatorname{site}=\& x=0 \& y=0>$

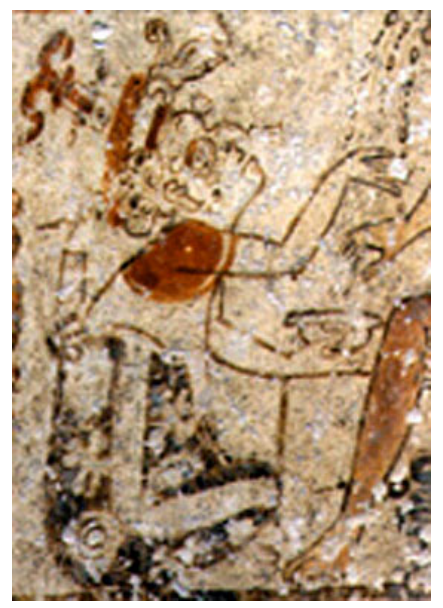

Fig. 10. Vaso K6020 (detalle) [online]. FAMSI [acceso: 2017-06-05]. Disponible en: $<$ http://research.mayavase.com/kerrmaya_list.php?_allSearch=\&hold_search=\&vase_nu mber $=6020 \&$ date_added $=\& m s \_n u m b e r=\& s i t e=\& x=0 \& y=0>$ 


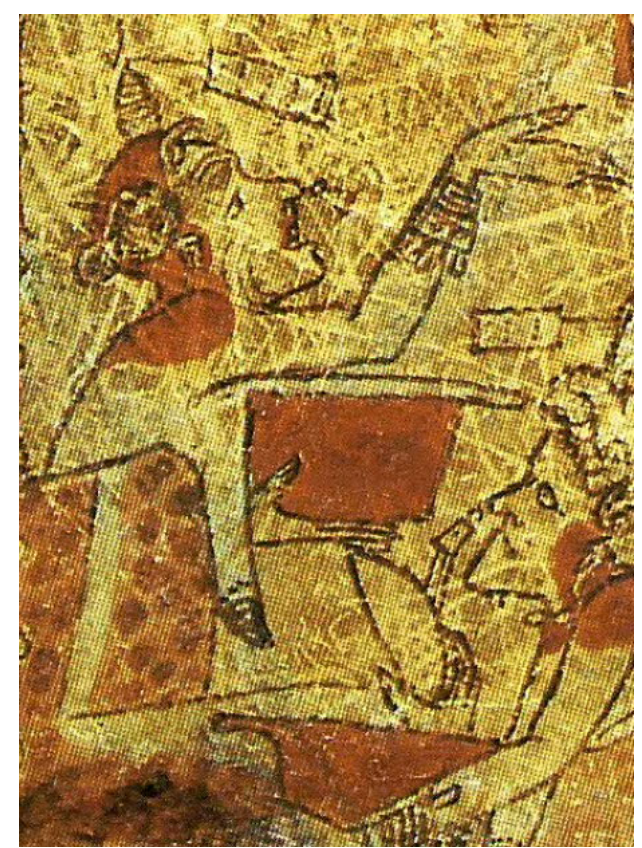

Fig. 11. Vaso del Nacimiento, K5113, lado 2 (detalle) [online]. FAMSI [acceso: 2017-06-05]. Disponible en: <http://www.mayavase.com/5113/birthvase.html>

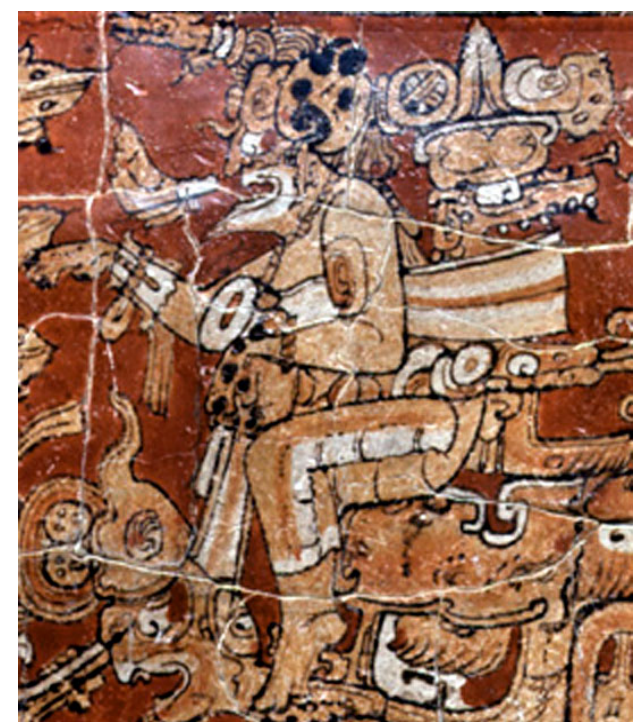

Fig. 12. Vaso K0501 (detalle) [online]. FAMSI [acceso: 2017-06-05]. Disponible en: $<$ http://research.mayavase.com/kerrmaya_list.php?_allSearch=\&hold_search=\&vase_nu mber $=501 \&$ date_added $=\& m s \_$number $=\& s i t e=\& \mathrm{x}=0 \& \mathrm{y}=0>$ 


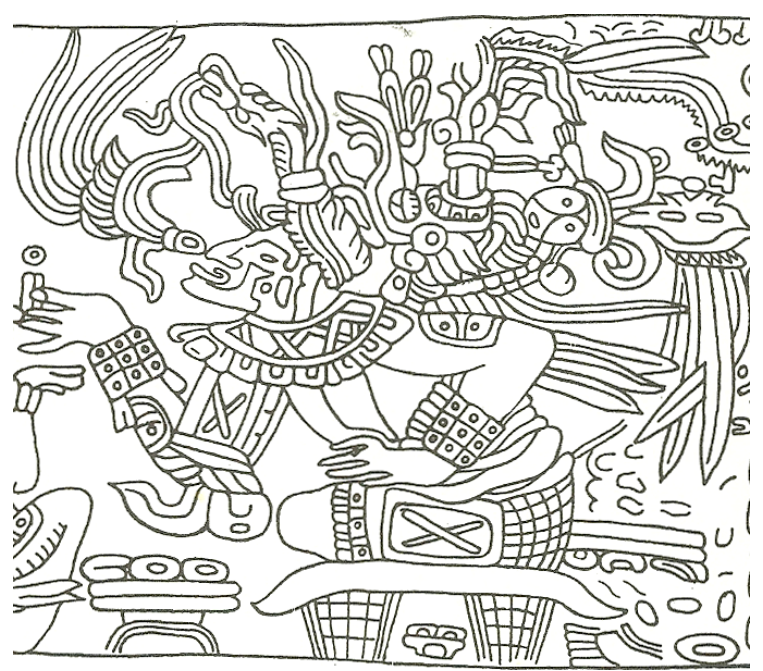

Fig. 13. Vaso en F. Anton, Art of the Maya, fig. 46 (detalle)

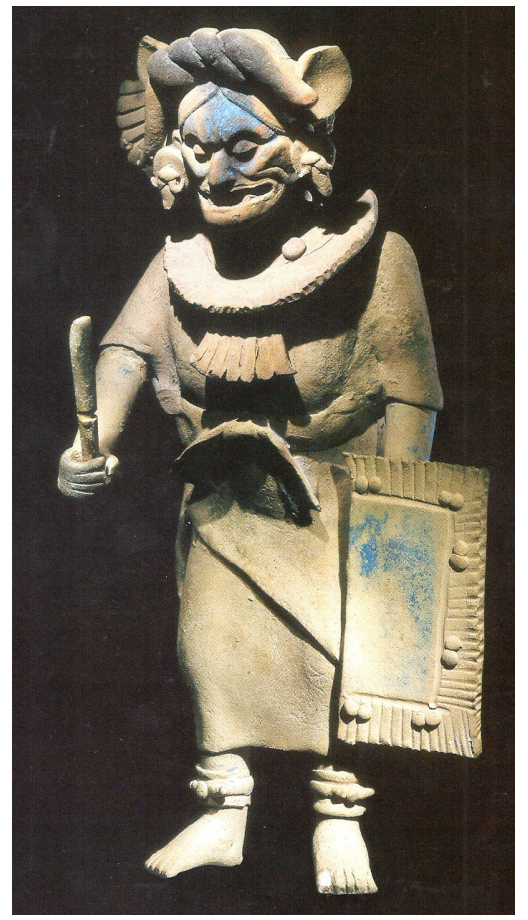

Fig. 14. Figurilla femenina, fotografía de Jorge Pérez de Lara, en L. Schele, Rostros Ocultos, p. 165 


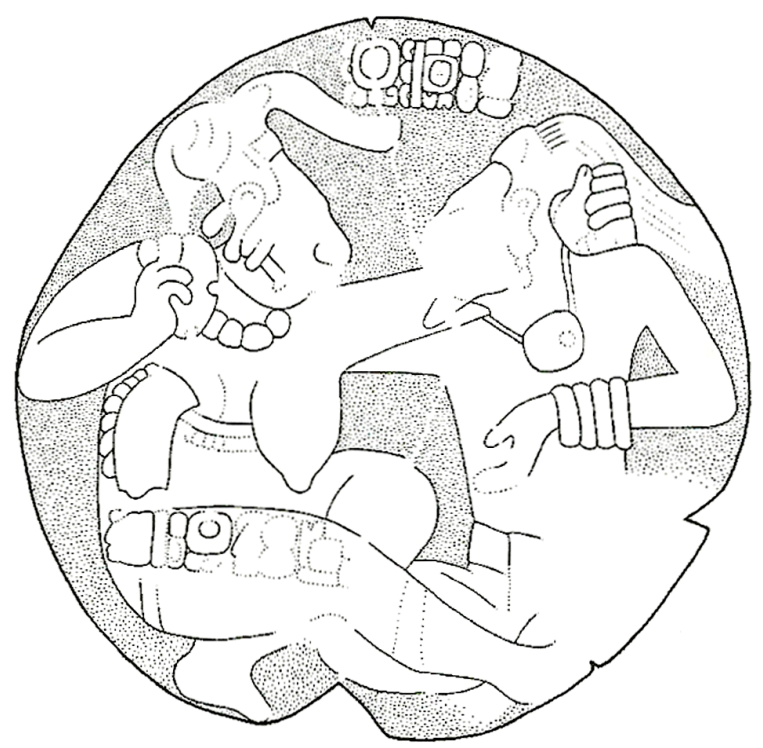

Fig. 15. Monumento 148, Toniná. Dibujo de Julia Henderson, S.D. Houston, D. Stuart, K.A. Taube, The Memory of Bones, p. 208, fig. 6.4

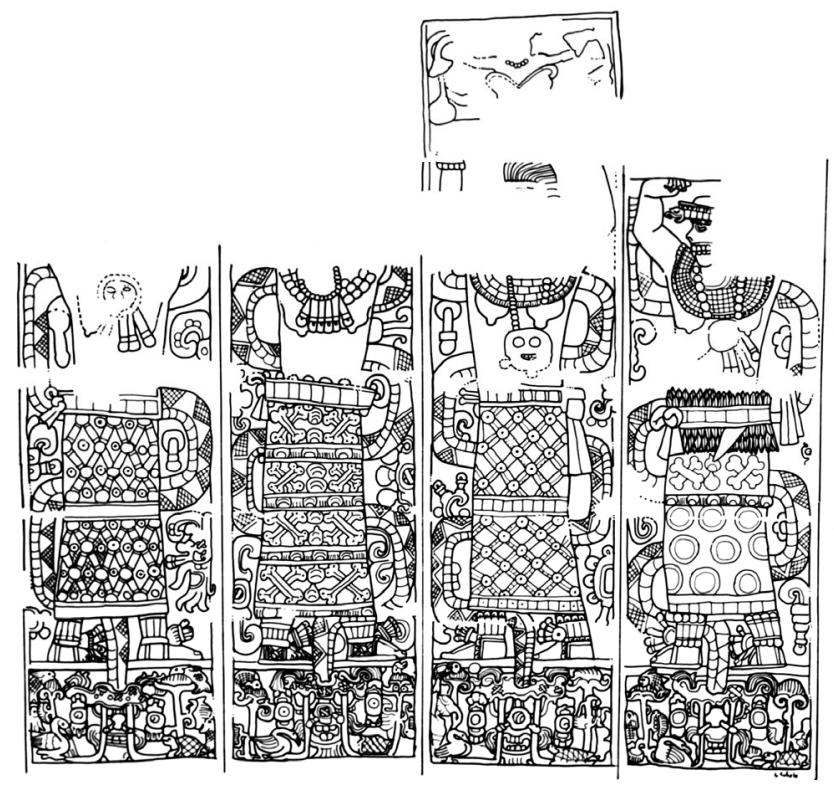

Fig. 16. Columna interior Norte del Templo Inferior de los Jaguares, Chichén Itzá. Dibujo de Linda Schele, № 5044 [online]. FAMSI [acceso: 2017-06-02]. Disponible en: $<$ http://research.famsi.org/uploads/schele/hires/08/IMG0005.jpg > 


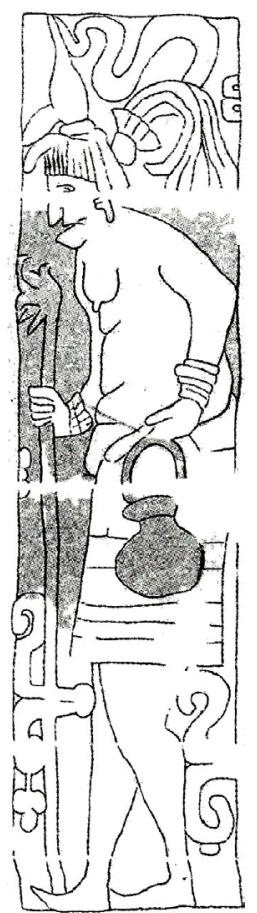

Fig. 17. Columna 16, lado Este, Templo de los Guerreros, Chichén Itzá, en C.F. Baudez, Una historia de la religion, p. 274, fig. 108b

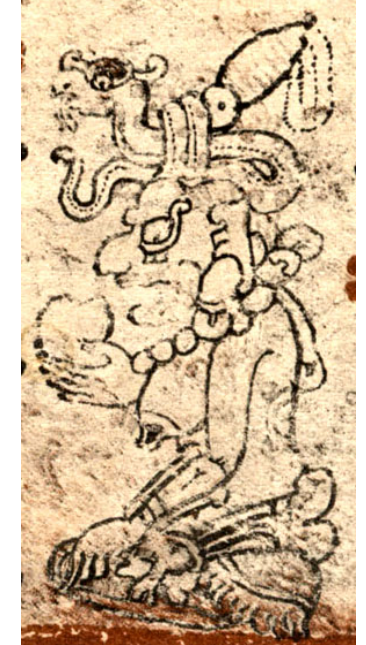

Fig. 18. Página 9c del Códice de Dresde, fotografía de Sächsische Landesbibliothek de Dresde (detalle) 


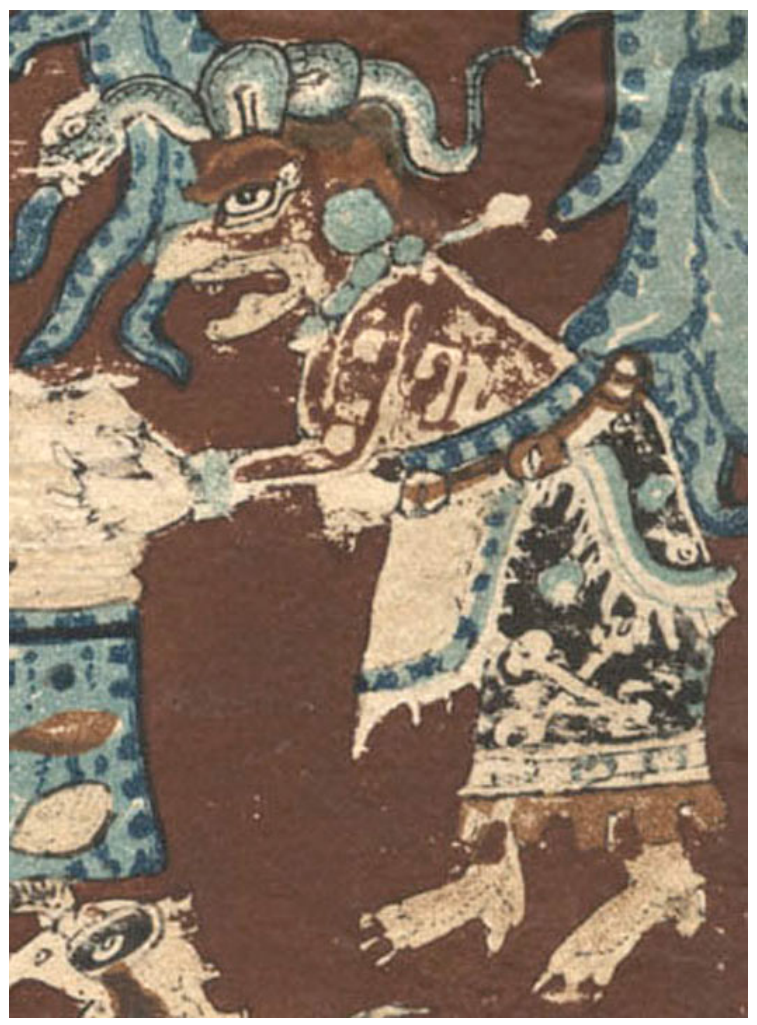

Fig. 19. Página 74 del Códice de Dresde, fotografía de Sächsische Landesbibliothek de Dresde (detalle)

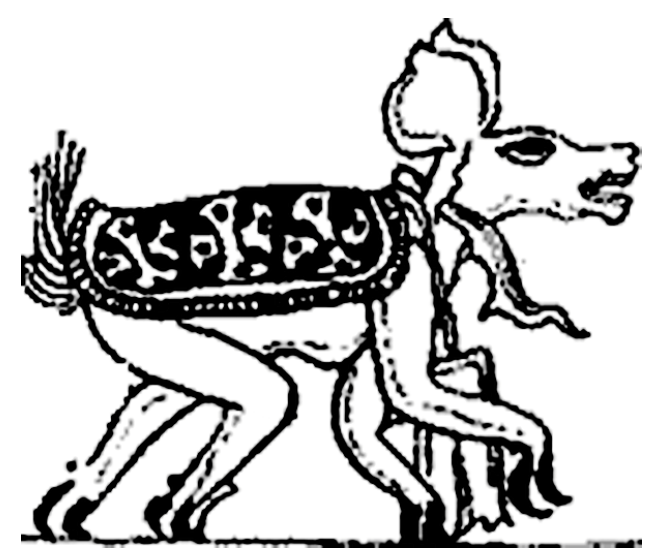

Fig. 20. Vaso Calcehtok, en H. Hernández Álvarez, Ideología de género femenino, fig. 5 (detalle) 


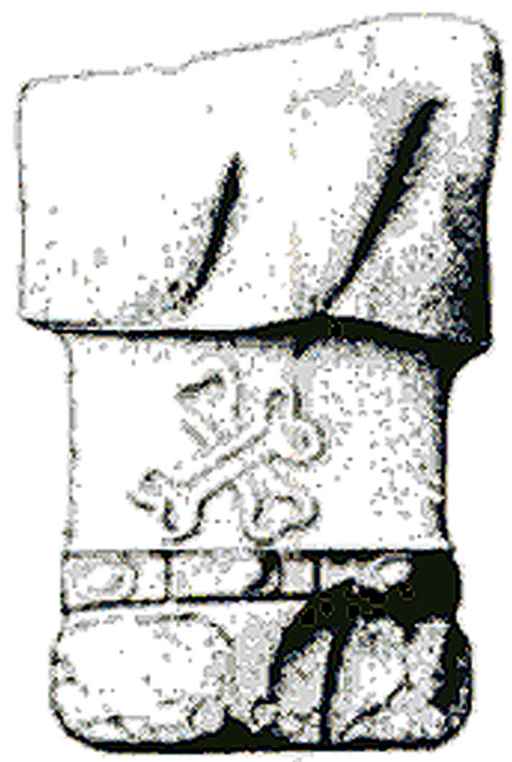

Fig. 21. Escultura del Palacio Chi'ch, Oxkintok, en M. Rivera Dorado, Una estatuilla de Ix Chel, p. 124

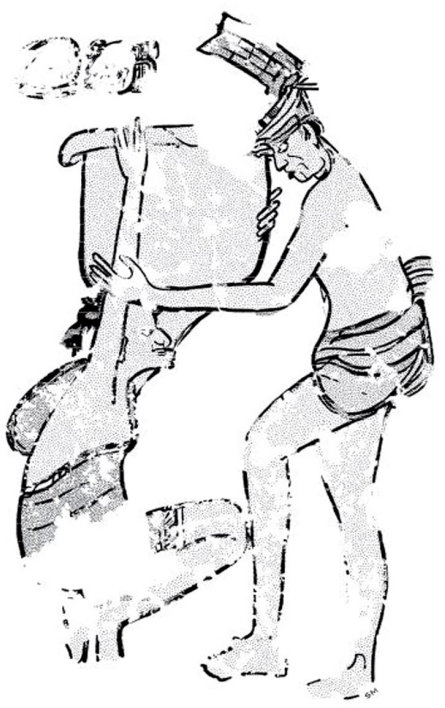

Fig. 22. Pintura de la Pirámide de las Pinturas, Calakmul. Dibujo de Simon Martin, en S. Martin, Hieroglyphs from the Painted Pyramid, p. 7, fig. 23 


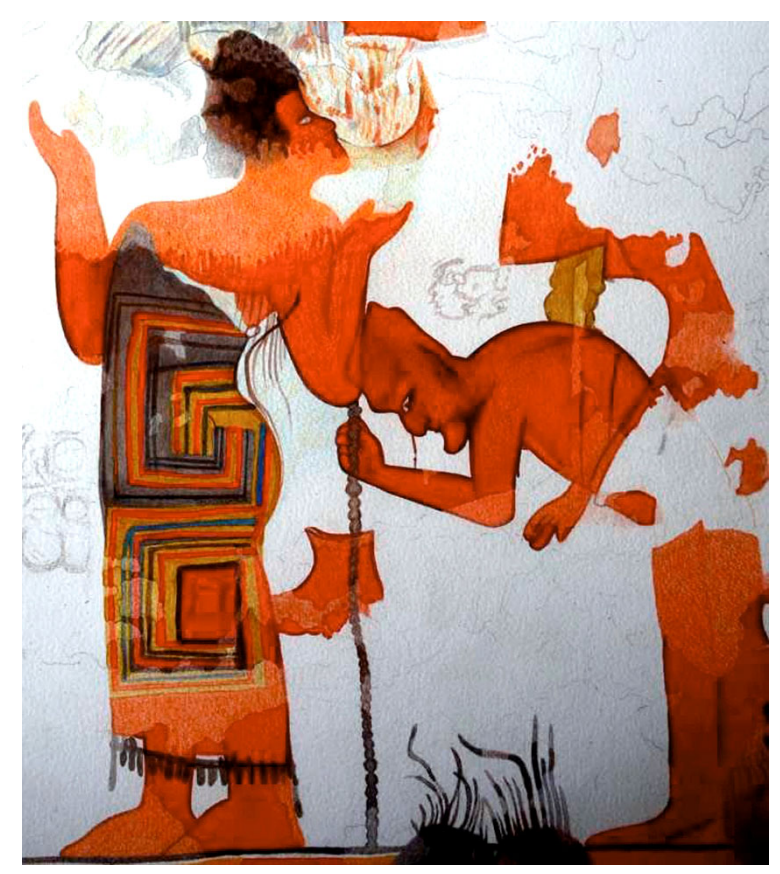

Fig. 23. Pintura de la Estructura 3E1, Chilonche. Dibujo de Miguel Ángel Núñez, Proyecto La Blanca 2013, en C. Vidal Lorenzo, G. Muñoz Cosme, Artistic Expressions in Maya Architecture, p. 172 (detalle)

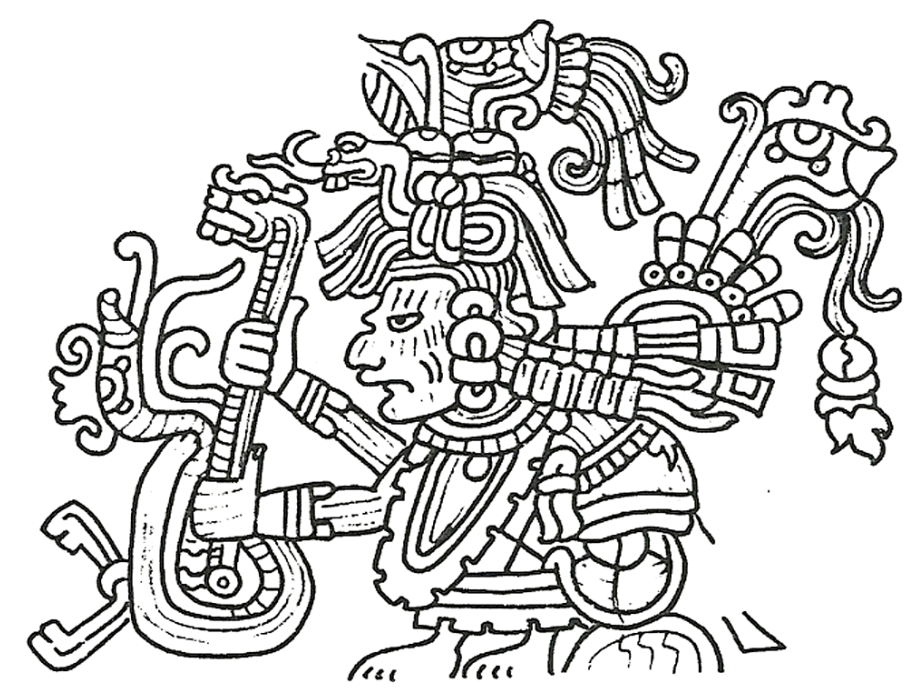

Fig. 24. Pintura mural de la Estructura 16, Tulum. Dibujo de Karl A. Taube, en K.A. Taube, The Major Gods of Ancient Yucatan, p. 102, fig. 51a 


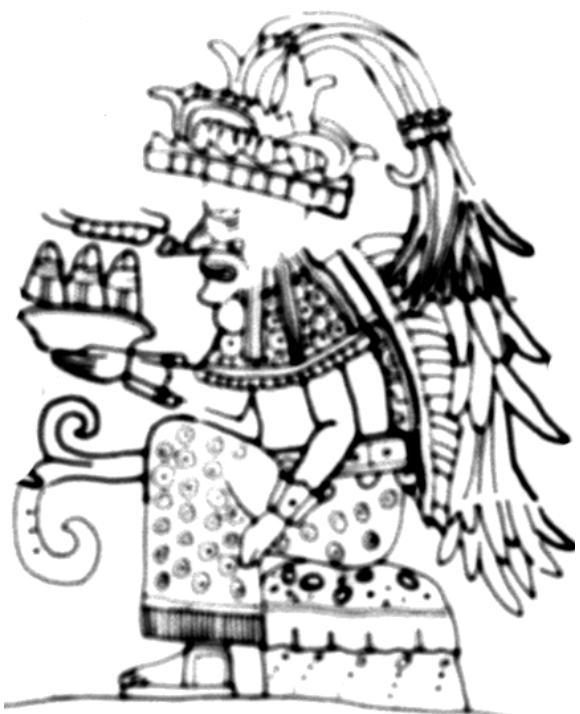

Fig. 25. Banca del Templo Chac Mool, Chichén Itzá. Dibujo de Linda Schele, No. 5064 [online]. FAMSI [acceso: 2017-06-02]. Disponible en:<http://www.famsi.org > (detalle)

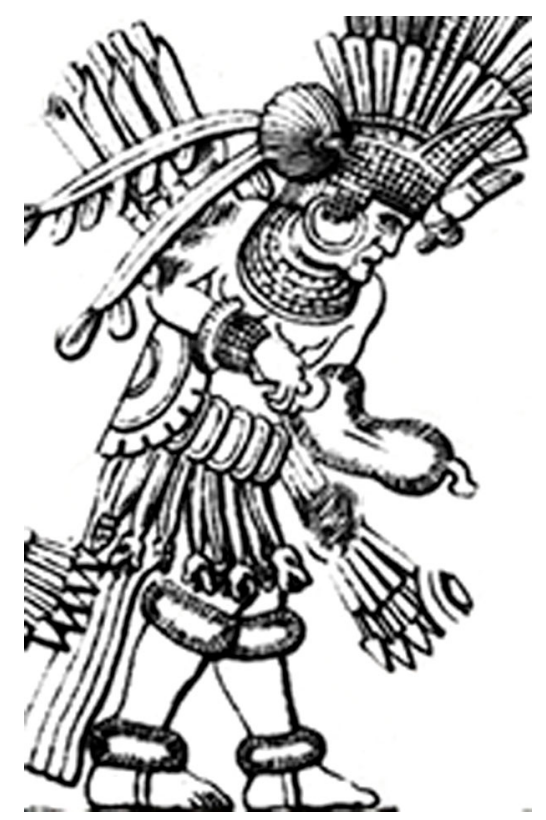

Fig. 26. Relieve del Registro C, Cámara E, del Templo Inferior de los Jaguares, Chichén Itzá. Dibujo de Linda Schele, en L. Schele, P. Mathews., The Code of Kings, p. 223, fig. 6.19 (detalle) 


\section{Bibliografía}

Acuña R., Bocabulario de Maya Than, Codex Vindobonensis, México 1993, p. XVII.

Anton F., Art of the Maya, London 1978.

Arzápalo Martín R., El Ritual de los Bacabes, México 1987.

Ayala Falcón M., Lady K'awil, Goddess O, and Maya Warfare, [en:] T. Ardren (dir.), Ancient Maya Women, Walnut Creek 2002, p. 105-113.

Barrera Vázquez A., Diccionario Maya Cordemex, México 1980.

Baudez C.F., Una historia de la religión de los antiguos mayas, México 2004.

Baudez C.F., Venus y el Códice Grolier, Arqueología Mexicana 55, 2002, pp. 70-79.

Baudez C.F., Riese B., Los bacab y los monstruos bicéfalos en la arquitectura de Copán, Yaxkin 9, 2, 1986, pp. 77-88.

Cervantes de Salazar F., Crónica de la Nueva España, México 1914-1936, p. XVI.

de Avendaño y Loyola A., Relación de las dos entradas que hice a la conversión de los gentiles itzaes y cehaches, Campeche 2004.

de Ciudad Real A., Calepino Maya de Motul, México 1995 [1551-1617].

de Herrera y Tordesillas A., Historia general de los hechos de los castellanos en las islas i tierra firme del mar oceano escrita por Antonio de Herrera, Madrid 1726-1730.

de Landa D., Relación de las cosas de Yucatán, México 1973 [1566].

de Las Casas B., Apologética historia sumaria, México 1967.

de Mendieta G., Historia eclesiástica indiana, México 1870.

Díaz del Castillo B., Historia verdadera de la conquista de la Nueva España, México 2005 [1632].

El libro de Chilam Balam de Chumayel, México 1991.

El libro de los Libros de Chilam Balam, México 2002 [1948].

Finamore D., Houston S.D., Fiery Pool. The Maya and the Mythic Sea, New Haven 2010.

García Valgañón R., La representación de las ancianas mayas prehispánicas de Tierras Bajas desde una perspectiva de género, Madrid 2016.

Halperin C.T., Maya Figurines: Intersections between State and Household, Austin 2014.

Hernández Álvarez H., Ideología de género femenino en la época prehispánica: diosas mayas con atuendos de sacrificios y muerte, Temas Antropológicos 28, 1-2, 2006, pp. 155-178.

Houston S.D., Stuart D., Taube K.A., The Memory of Bones: Body, Being, and Experience among the Classic Maya, Austin 2006.

Johansson P., Mocihuaquetzqueth ¿mujeres divinas o mujeres siniestras?, Estudios de Cultura Náhuatl 37, 2006, pp. 193-230.

Joyce R.A., Gender and Power in Prehispanic Mesoamerica, Austin 2000.

Klein C.F., The Devil and the Skirt: An Iconographic Inquiry into the Pre-Hispanic Nature of the Tzitzimime, Estudios de Cultura Náhuatl 31, 2000, pp. 16-74.

Laporte J.P., El embrujo del tecolote y otras historietas: Algunas consideraciones sobre los silbatos del Clásico en Tikal, [en:] B. Arroyo, J.P. Laporte, H. Mejía (dir.), XXII Simposio de Investigaciones Arqueológicas en Guatemala, Guatemala 2009, pp. 1021-1050.

León Portilla M., Cihuayotl iixco ca: la femineidad luce en su rostro, Arqueología mexicana 29, 1998, pp. 14-19.

López Medel T., Ordenanzas para la provincia de Yucatán (1552-1553), [en:] A. Tozzer (dir.), Landa's Relacion de las cosas de Yucatan. A translation, Cambridge 1941, pp. 203-219.

Martin S., Hieroglyphs from the Painted Pyramid: The Epigraphy of Chiik Nahb Structure Sub 1-4, Calakmul, México, [en:] Ch. Golden, S.D. Houston, J. Skidmore, Maya Archaeology 2, San Francisco 2012, pp. 60-81.

Martin S., Miller M.E., Courtly Art of the Ancient Maya, London 2004.

Máynez P., El calepino de Sahagún: un acercamiento, México 2002.

Mathews P., Schele L., The Code of Kings: The Language of Seven Sacred Maya Temples and Tombs, New York 1998. 
Médiz Bolio A., Libro de Chilam Balam de Chumayel, [en:] M. de la Garza (dir.), Literatura maya, Caracas 1980, pp. 217-288.

Moya Honores P., La representación material de los roles femeninos y las relaciones de género en las figurillas de la Isla de Jaina, Tesis de maestría, México 2006.

Noemí Prieto V., Villanueva y Villanueva N.B., Rituales de hetzmek en Yucatán, Estudios de Cultura Maya 33, 2009, pp. 73-103.

Patel S., Pilgrimage and Caves on Cozumel, [en:] J.E. Brady, K.M. Prufer, Stone Houses and Earth Lords: Maya Religion in the Cave Context, Boulder 2005, pp. 91-112.

Popol Vuh, México 2000.

Recinos A., Códice de Calkiní, [en:] M. de la Garza (dir.), Literatura maya, Caracas 1980, pp. 425-441.

Redfield R., Villa Rojas A., Chan Kom: A Maya Village, Washington 1964 [1934].

Rivera Dorado M., Una estatuilla de Ix Chel, Oxkintok, [en:] Oxkintok 2, Madrid 1989, pp. 121-126.

Sahagún B., Historia General de las cosas de Nueva España, México 1929.

Sahagún B., Florentine Codex: Book, The Ceremonies, Santa Fe 1951.

Schele L., Mathews P., The Code of Kings: The Language of Seven Sacred Maya Temples and Tombs, New York 1998.

Schele L., Rostros Ocultos de los mayas, México 1997.

Seler E., Gesammelte Abhandlungen zur Amerikanischen Sprach- und Alterthumskunde, Berlin 1902-1923.

Stephens J.L., Incidentes de viaje en Centroamérica, Chiapas y Yucatán, Costa Rica 1971 [1841].

Stone A., Vail G., Representations of Women in Postclassic and Colonial Maya Literature and Art, [en:] T. Ardren (dir.), Ancient Maya Women, Walnut Creek 2002, pp. 203-228.

Taube K.A., Ritual Humor in Classic Maya Religion, [en:] W.F. Hanks, D.S. Rice (dir.), Word and Image in Maya Culture, Salt Lake City 1989, pp. 351-382.

Taube K.A., The Major Gods of Ancient Yucatan, Washington 1992.

Taube K.A., The Birth Vase: Natal Imagery in Ancient Maya Myth and Ritual, [en:] The Maya Vase Book, New York 1994, pp. 652-685.

Tiesler Blos V., Rasgos bioculturales entre los antiguos mayas. Aspectos arqueológicos y sociales, México 1992.

Torquemada J.D., Monarquía indiana, México 1975-83.

Tiesler Blos V., Rasgos bioculturales entre los antiguos mayas. Aspectos arqueológicos y sociales, México 1992.

Triadan D., Warriors, Nobles, Commoners and Beasts: Figuries from Elite Buildings at Aguateca, Guatemala, Latin American Antiquity 18, 3, 2007, pp. 269-293.

Vail G., The Maya Hieroglyphic Codices [online]. Maya Codices [acceso: 2002-02-13]. Disponible en: <http://www.mayacodices.org $>$.

Vidal Lorenzo C., Muñoz Cosme G., Artistic Expressions in Maya Architecture: Analysis and Documentation Techniques, BAR International 2693, Oxford 2014. 
